\title{
Differential Effects of Activated Protein C on Synovial Fibroblasts in Response to Hypoxia and Normoxia
}

(Perbezaan Kesan Protein C yang Diaktifkan pada Sinovium Fibroblas dalam Tindak Balas kepada Hipoksia dan Normosia)

\author{
YANG-GYU PARK, JAWUN CHOI, INKYU SONG, CHRISTOPHER J. JACKSON, \\ SANG-YOUEL PARK \& JAE-WON SEOL*
}

\begin{abstract}
Rheumatoid arthritis (RA) is a chronic disease characterized by inflammation of the joints and their lining or synovium. Previous studies showed that the synovium in RA patients is more hypoxic than normal synovium. Activated protein $C$ (APC) has anticoagulant and anti-inflammatory effects and is highly expressed in the joints of RA patients. We examined the effect of APC on RA and normal synovial fibroblasts under hypoxic conditions. Human synovial fibroblasts were isolated from the synovial tissues of RA patients and normal controls and cells were exposed to recombinant APC under normoxic (21\% oxygen) or hypoxic (1\% oxygen) conditions. Cell proliferation was measured using MTT assays. Cell lysates and conditioned media were collected and assayed for matrix metalloproteinase (MMP)-2, MMP-9 and p38 using zymography and western blots. Proliferation of both normal and RA synovial fibroblasts dose-dependently increased after APC treatment in normoxic conditions. Under hypoxia, APC enhanced RA cell proliferation but had no effect on normal fibroblasts. MMP-2 production and activation were significantly augmented by APC in both cell types under normoxia and hypoxia conditions. However, activated MMP-2 was more reduced in cells under hypoxia than normoxia. APC substantially reduced the phosphorylation of $\mathrm{p} 38$ in normal and RA synovial fibroblasts under hypoxia. No difference in $\mathrm{p} 38$ phosphorylation was observed under normoxia. The receptor for APC, endothelial protein $C$ receptor (EPCR), was elevated in normal fibroblasts under hypoxic conditions whereas in RA cells, EPCR was highly expressed under both normoxic and hypoxic conditions. We found that hypoxia enhanced the effect of APC on RA synovial fibroblasts through activation of MMP2 and inhibition of $\mathrm{p} 38$ phosphorylation. Our results suggested that APC may suppress joint destruction and progression of inflammation in a hypoxic RA environment.
\end{abstract}

Keywords: Activated protein C; hypoxia; MMP-2; rheumatoid arthritis; synovial fibroblast

ABSTRAK

Reumatoid artritis (RA) adalah penyakit kronik yang dicirikan oleh keradangan sendi serta lapisan atau sinovium. Kajian terdahulu menunjukkan bahawa sinovium dalam pesakit RA lebih hipoksik daripada sinovium biasa. Protein yang diaktifkan $C(A P C)$ mempunyai kesan antikoagulan dan anti-radang yang sering terjadi dalam sendi pesakit RA. Kami mengkaji kesan APC pada RA dan sinovium fibroblas normal dalam keadaan hipoksia. Sinovium fibroblas manusia telah diasingkan daripada tisu sinovium pesakit RA dan kawalan normal, dan sel terdedah kepada APC rekombinan dalam keadaan oksigen (21\% oksigen) atau hipoksik (1\% oksigen). Proliferasi sel diukur menggunakan ujian MTT. Sel lisat dan media bersyarat dikumpulkan dan diuji pada matriks metaloproteinase (MMP) -2, MMP-9 dan p38 menggunakan zimografi dan western blots. Proliferasi pada kedua-dua dos biasa sinovium fibroblas dan RA meningkat bergantung pada rawatan APC dalam keadaan normosik. Di bawah hipoksia, APC meningkatkan percambahan sel RA tetapi tidak mempunyai kesan pada fibroblas biasa. Pengeluaran dan pengaktifan MMP-2 secara signifikan ditambah oleh APC dalam kedua-dua jenis sel di bawah keadaan normoksia dan hipoksia. Walau bagaimanapun, MMP-2 diaktifkan berkurangan dalam sel di bawah hipoksia daripada normoksia. APC secara substansial mengurangkan fosforilasi p38 dalam sinovium fibroblas normal dan RA di bawah hipoksia. Tiada perbezaan dalam 338 fosforilasi diperhatikan di bawah normoksia. Reseptor untuk APC dan reseptor protein endotelium C (EPCR) dinaikkan pada fibroblas biasa di bawah keadaan hipoksik manakala dalam sel RA, EPCR dinyatakan di bawah kedua-dua keadaan normoksik dan hipoksik. Kami mendapati bahawa hipoksia meningkatkan kesan APC terhadap sinovium fibroblas RA melalui pengaktifan MMP2 dan perencatan p38fosforilasi. Keputusan kami mencadangkan supaya APC dapat menghentikan kemusnahan sendi dan perkembangan keradangan dalam persekitaran RA hipoksik.

Kata kunci: Hipoksia; MMP-2; protein C diaktifkan; reumatoid artritis sinovium fibroblas 


\section{INTRODUCTION}

Rheumatoid arthritis (RA) is a chronic autoimmune disease typically characterized by inflammation of the joints and their lining or synovium (Xue et al. 2007). RA chiefly affects joints and ultimately leads to joint tissue destruction. The symptoms of RA include deformed joints, pain and swelling. Therefore, early diagnosis and prevention of RA is important. However, precise causes of RA are not fully understood. Recent studies showed that the synovium in RA patients is more hypoxic than normal synovium and hypoxia-related signaling regulates pro-inflammatory pathways in RA (Akhavani et al. 2009; Gao et al. 2015). Furthermore, oxygen pressure is decreased in the RA synovium compared with normal joints (Paleolog 2009).

Synovial hypoxia is a prominent feature of RA (Akhavani et al. 2009; Del Rey et al. 2010; Ryu et al. 2014). Under hypoxic conditions, low oxygen levels are associated with expression of hypoxia-inducible factors (HIFs) and increased pro-inflammatory cytokines (Melillo 2011). HIFs principally drive the cellular response under hypoxia, through interaction with hypoxia-responsive elements that leads to gene expression (Rankin \& Giaccia 2008). In particulars, HIFs are increased in RA-affected joints, HIFs increase inflammatory cell infiltration and inflammatory-mediated products such as p38 and nuclear factor-kappa B (NF-kB) (Konisti et al. 2012).

Activated protein $\mathrm{C}$ (APC) results from conversion of protein $\mathrm{C}$ and has cytoprotective anti-inflammatory, anti-apoptotic, and anticoagulant activities (Danese et al. 2010; McKelvey et al. 2014; Minhas et al. 2010). APC is triggered by the thrombin-thrombomodulin complex and appears on the endothelial cell surface (Jackson et al. 2014; Xue \& Jackson 2015). The presence of the APC-specific receptor endothelial protein $\mathrm{C}$ receptor (EPCR) augments conversion to APC (Xue et al. 2007). EPCR is expressed on the surface of cells including endothelial cells and leukocytes (Lee et al. 2013; Seol et al. 2011; Thiyagarajan et al. 2007). EPCR is also expressed in other cells that have anti-inflammatory activity mediated by APC (Bouwens et al. 2013; Lee et al. 2013; Thiyagarajan et al. 2007; Xue et al. 2014). The anti-inflammatory activity of APC is associated with decreased leucocyte recruitment and proinflammatory mediators (Esmon 2012; Minhas et al.2010). APC reduces inflammation by regulating $p 38$ activity by activating protease-activated receptor-2 (PAR-2) (Julovi et al. 2011). APC is elevated in RA synovial joints and fluids and co-localizes with matrix metalloproteinase (MMP)-2 in the lining layer (Buisson-Legendre et al. 2004; Xue et al. 2014).

MMP-2 is a member of the MMPs. Among this subfamily, the gelatinase subfamily includes MMP-2 and MMP-9 (Sela-Passwell et al. 2010). MMPs are key mediators of inflammation and RA (Bauvois 2012; Xue \& Jackson 2015). In addition, activation and expression of MMP-2 are stimulated by APCs in endothelial cells and fibroblasts (Lee et al. 2013). Previous studies showed that MMP-9 is decreased by APC in the ischemic brain (Cheng et al. 2006).
Furthermore, APC inhibits MMP-9 expression and stimulates MMP-2 activation and expression in synovial fibroblasts from RA patients and normal adults (Jackson et al. 2009; Xue et al. 2007, 2004). However, the effect of APC on RA and normal fibroblast cells under hypoxic conditions is not fully understood.

To understand how synovial cells and chondrocytes behave in different oxygen tensions deep in the cartilage and during joint diseases such as RA, we examined APC effects on normal and RA synovial fibroblasts under normoxic $\left(21 \% \mathrm{O}_{2}\right)$ and hypoxic $\left(1 \% \mathrm{O}_{2}\right)$ conditions. Exposure to normoxia and hypoxia showed that APC treatment decreased phosphorylation of $p 38$ in hypoxic conditions. Our results indicated that APC exerted a protective effect on RA synovial fibroblasts by inhibiting pro-inflammatory $p 38$ and NF-kB and increasing antiinflammatory MMP-2 under hypoxic conditions.

\section{MATERIALS AND METHODS}

\section{ISOLATION AND TREATMENT OF CELLS}

Human synovial fibroblasts were isolated from the synovial tissues of RA patients during joint replacement surgery according to American College of Rheumatology criteria (Arnett et al. 1988). Tissues were minced and digested with $2 \mathrm{mg} / \mathrm{mL}$ collagenase (Sigma-Aldrich, St. Louis, MO, USA) in Dulbecco's modified Eagle medium (DMEM) containing $100 \mathrm{U} / \mathrm{mL}$ penicillin/streptomycin, $10 \mathrm{mmol} / \mathrm{L}$ HEPES (all from Gibco BRL/Life Technologies, Carlsbad, CA, USA) and $3.7 \mathrm{~g} / \mathrm{L} \mathrm{NaHCO} 3$ at $37^{\circ} \mathrm{C}$ for $3 \mathrm{~h}$, followed by digestion with $0.25 \%$ trypsin and $0.02 \%$ ethylenediaminetetraacetic acid at $37^{\circ} \mathrm{C}$ for $30 \mathrm{~min}$. Cells were cultured in DMEM containing $10 \%$ fetal bovine serum (ICN, Aurora, OH, USA) in $75 \mathrm{~cm}^{2}$ flasks at $37^{\circ} \mathrm{C}$ in a humidified $5 \% \mathrm{CO}_{2}$ atmosphere. Synovial cells were exposed to recombinant APC (Xigris; Eli Lilly, Indianapolis, IN) $(0.1,1,10$ and $20 \mu \mathrm{g} / \mathrm{mL})$ under normoxic $\left(21 \% \mathrm{O}_{2}\right)$ and hypoxic $(1 \%$ $\mathrm{O}_{2}$ ) conditions. Ethical approval was granted by the Royal North Shore Animal care and Ethics Committee and Northern Sydney Health Human Research Ethics Committee.

\section{CELL PROLIFERATION ASSAYS}

Cell proliferation assays were performed as described previously (Julovi et al. 2011). Cells $\left(2 \times 10^{3}\right.$ cells/well $)$ were seeded into 96-well microplates to a final volume of $200 \mu \mathrm{L}$ and incubated for $4 \mathrm{~h}$ to allow cells to attach. After preincubation for $12 \mathrm{~h}$, cells were treated with APC for 72 $\mathrm{h}$ in serum-free conditions under normoxic and hypoxic conditions. Cells were stained with $1 \mu \mathrm{g} / \mathrm{mL}$ crystal violet (Sigma-Aldrich) dissolved in phosphate buffered saline (PBS). Unbound dye was removed by washing with tap water. Bound crystal violet was solubilized with $0.1 \%$ sodium dodecyl sulfate (SDS) in PBS. Optical density of wells was determined at $550 \mathrm{~nm}$ wavelength. The results were expressed relative to control. 


\section{GELATINE ZYMOGRAPHY}

In order to determine if APC directly activated gelatinases MMP-2 and MMP-9, cells were incubated with APC; 6-AQ (1 $\mu \mathrm{g} / \mathrm{mL})$, a specific inhibitor of NF-kB activation; or a $p 38$ inhibitor $(100 \mathrm{nM})$ for $72 \mathrm{~h}$ under normoxic and hypoxic conditions. MMP- 2 activation in culture medium and cells was measured using gelatin zymography (Ruf 2004). Culture supernatants and cell lysates were loaded onto $10 \%$ SDS gels containing $0.5 \mathrm{mg} / \mathrm{mL}$ gelatin. Relative levels of MMP-2 were semiquantified using the Gel-Pro Analyzer (Media Cybernetics, Bethesda, MD).

\section{WESTERN BLOTS}

Cells were washed three times with PBS before lysis buffer $(0.15 \mathrm{M} \mathrm{NaCl}, 0.01 \mathrm{mM}$ PMSF, $1 \%$ NP-40, $0.02 \mathrm{M}$ Tris, 6 $\mathrm{M}$ urea/H2O) was added. Cell lysates were centrifuged at $10,000 \times \mathrm{g}$ for $15 \mathrm{~min}$ and total protein concentration was determined using BCA protein assay kits (Pierce Biotechnology, Rockford, IL, USA). Equal amounts of protein were separated by $8-15 \%$ SDS-polyacrylamide gel electrophoresis and Western blots were as previously described (Xue et al. 2005). Primary antibodies were rabbit antihuman EPCR (Santa Cruz Biotechnology, Santa Cruz, CA, USA), mouse antihuman MMP-9 (ab137867, Abcam $^{\circledR}$, UK) and MT1-MMP (Chemicon International, Inc., Temucula, CA, USA), rabbit antihuman phosphorylated $p 38$ (Santa Cruz Biotechnology) or mouse anti human NF-kB (Chemicon). Antihuman beta-actin was included to correct for unequal loading.

\section{IMMUNOFLUORESCENCE}

Cells were cultured on gelatin $(0.2 \% \mathrm{w} / \mathrm{v})$-coated fourchamber glass slides and incubated with APC before processing for immunofluorescent staining as previously described (Riewald et al. 2002). Briefly, cells were fixed with cold acetone, blocked by $5 \%$ donkey serum in PBS and incubated with goat polyclonal antibody against proteaseactivated receptor (PAR)-1 or mouse monoclonal antibody against PAR-2 (Santa Cruz Biotechnology) overnight at $4^{\circ} \mathrm{C}$. After three washes with PBS, cells were incubated with antimouse $\mathrm{IgG}$ conjugated with $\mathrm{Cy} 3$ or antigoat $\mathrm{IgG}$ conjugated with fluorescein isothiocynate. Cells were washed with PBS and mounted in fluorescence medium. Cells were observed with an Eclispse 80i fluorescence microscope (Nikon Corporation, Tokyo, Japan).

\section{HYPOXIC CONDITIONS}

A hypoxic chamber was used to culture synovial fibroblasts at low oxygen tension $\left(1 \% \mathrm{O}_{2}\right)$. For normoxic conditions $\left(21 \% \mathrm{O}_{2}\right)$, synovial fibroblasts were incubated at $37^{\circ} \mathrm{C}$ in a $95 \%$ humidified atmosphere with $5 \% \mathrm{CO}_{2}$.

\section{STATISTICAL ANALYSIS}

Statistical differences were analyzed using Student's $t$-test. ANOVA was used to compare means among three or more independent groups, followed by the Newman-Keuls post-hoc test. Results are displayed as mean \pm standard deviation (SD).

\section{RESULTS}

\section{APC INCREASES SYNOVIAL FIBROBLAST PROLIFERATION AND ACTIVATION OF MMP-2 UNDER HYPOXIA}

In order to explore effects of APC under hypoxic conditions, we used normal synovial fibroblasts (NFb) and RA synovial fibroblasts (RAFb). We examined the effect of APC on cell proliferation under normoxia and hypoxia. In NFb cells, cell proliferation by APC treatments was increased under normoxic condition. Furthermore, cell proliferation of $\mathrm{RAFb}$ increased with APC under normoxic or hypoxic condition (Figure 1). When RAFb were treated with APC under hypoxic conditions, cell proliferation was increased (Figure 1(b)). APC treatment induced MMP-2 activation and expression in $\mathrm{NFb}$ and $\mathrm{RAFb}$ under normoxic and hypoxic conditions. However, APC induction of MMP-2 activation in hypoxic conditions was lower than in normoxic conditions (Figure 1).

\section{MMP EXPRESSION REGULATED BY APC IS DIFFERENT UNDER NORMOXIC AND HYPOXIC CONDITIONS}

We next examined APC-induced expression of MMPs MT1 and MMP-9 in NFb and RAFb under normoxic and hypoxic conditions. MMP-9 expression was decreased by APC in $\mathrm{NFb}$ and RAFb under normoxic conditions. MMP-9 was slightly decreased after APC treatment of NFb under hypoxic conditions. MT1 MMP expression was not affected (Figure 2(a)). In RAFb under hypoxic conditions, MMP expression was similar to NFb under hypoxic conditions (Figure 2). MMP expression differed between normoxic and hypoxic conditions: Under hypoxic conditions, MMP expression was reduced relative to normoxic conditions.

\section{HYPOXIA AUGMENTS APC-INDUCED INFLAMMATORY MEDIATORS IN SYNOVIAL FIBROBLASTS}

We next investigated whether APC regulated inflammatorymediated products in NFb and RAFb under hypoxic conditions. We examined if APC regulated PAR-1 and PAR-2 in RAFb under hypoxic conditions. APC treatment increased PAR-1 and PAR-2 expression (Figure 3(a)). Subsequently, we tested expression of inflammatory-mediated products with APC under hypoxic conditions (Figure 3). In NFb under normoxic conditions, EPCR expression increased with APC treatment. Under hypoxic conditions, EPCR expression did not change with APC (Figure 3(b)). However, total EPCR expression was higher than in normoxic conditions. These experiments showed that under hypoxic conditions, APC treatment downregulated phosphorylated p38 and NF-kB expression (Figure 3(b) \& 3(c)). Expression of phosphorylated p38 was observed only under hypoxic conditions (Figure 3). 
(a)

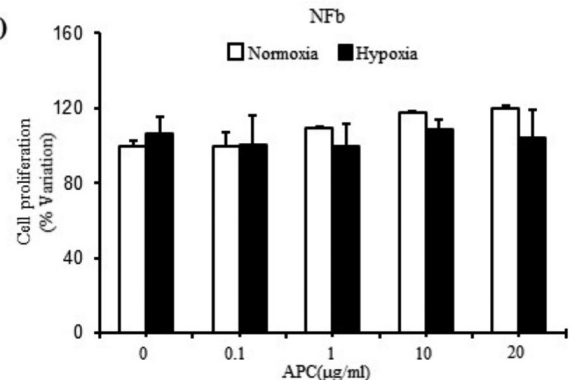

(c)

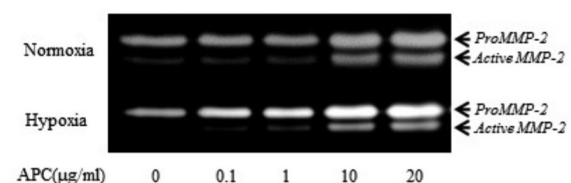

(e)

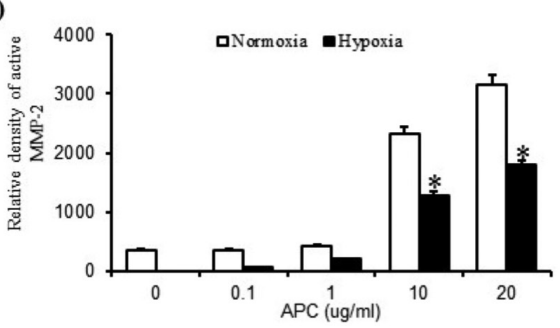

(b)

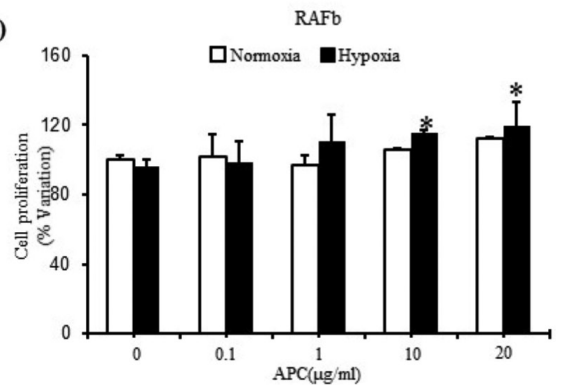

(d)

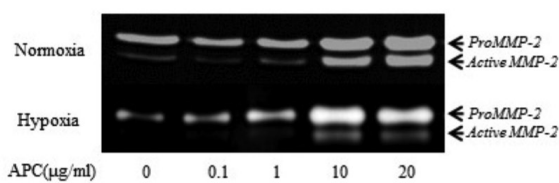

(f)

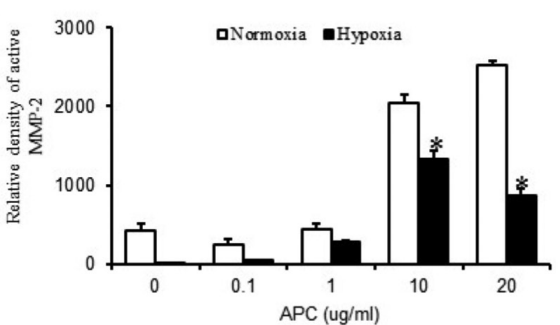

FIGURE 1. Cell proliferation and matrix metalloproteinase activation of synovial fibroblasts by APC under normoxia and hypoxia. (a) and (b) proliferation of NFb and RAFb in response to APC treatment for $72 \mathrm{~h}$ under normoxia $(21 \% \mathrm{O} 2)$ and hypoxia $(1 \% \mathrm{O} 2)$ detected by crystal violet staining. Cell proliferation is expressed as percent of control (mean $\pm \mathrm{SD}$ ), (c) and (d) NFb and RAFb were treated with activated protein $\mathrm{C}$ (APC; $0.1,1,10$ and $20 \mu \mathrm{g} / \mathrm{mL}$ ) for $72 \mathrm{~h}$ under normoxia and hypoxia. Matrix metalloproteinase (MMP)-2 in culture supernatants by zymography, (e) and (f) Activated MMP-2

expression in (c), (d) determined by densitometry. Three independent experiments show similar results. $* p<0.05$ versus normoxia by one-way ANOVA

(a)

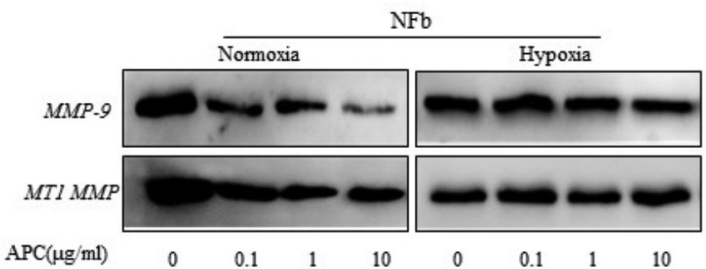

(b)

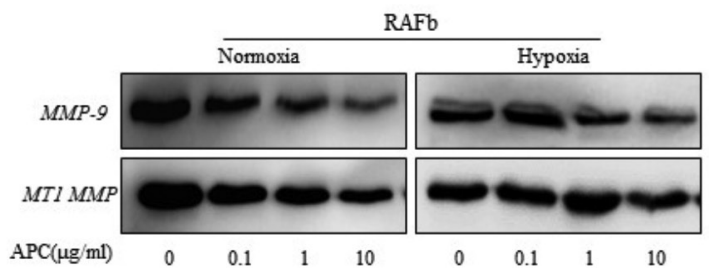

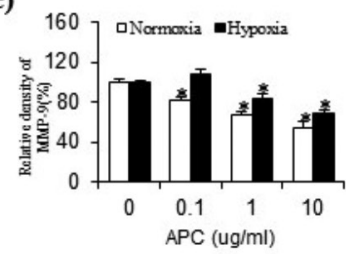

(f)

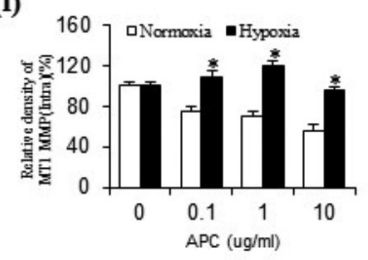

(e)
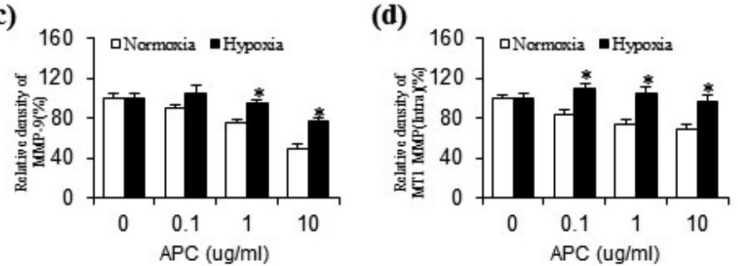

FIGURE 2. Expression of MT1, MMP and MMP-9 in synovial fibroblasts with APC under normoxia and hypoxia. (a) and (b) $\mathrm{NFb}$ from normal patients and RAFb from RA were treated with activated protein C (APC; $0.1,1,10$ and $20 \mu \mathrm{g} / \mathrm{mL}$ ) for $72 \mathrm{~h}$ under normoxia $(21 \% \mathrm{O} 2)$ and hypoxia $(1 \% \mathrm{O} 2)$ and cell lysates and supernatants were collected for Western blots, (c) and (d) MMP-9 and MT1 MMP (intracellular) expression in (a), (e) and (f) and MMP-9 and MT1 MMP (intracellular) expression in (b) were measured by densitometry, Density was calculated as expression versus control. Three independent experiments showed similar results. ${ }^{*} p<0.05$ versus normoxia by one-way ANOVA 


\section{ANTI-INFLAMMATORY ACTIVITY OF APC THROUGH P38} PHOSPHORYLATION UNDER HYPOXIA

Under hypoxic conditions, $p 38$ phosphorylation and NF-kB activation increased. These events were interdependent with inflammation. Thus, we tested the effect of APC on p38 and NF-kB under hypoxic conditions using the $p 38$ inhibitor SB203580 and the NF-kB inhibitor 6-AQ. We tested the activation of MMP- 2 by APC under hypoxic conditions and found that active MMP- 2 increased in culture supernatants with APC treatment, whereas APC did not affect MMP-2 activation in cells (Figure 4(a)). Similar results were observed with $p 38$ or NF-kB inhibitor and APC treatment. We verified APC-related inflammatory mediator expression in RAFb under hypoxic conditions (Figure 4(b)). Under hypoxic conditions, MMP-9 reduction by APC was blocked by NF-kB inhibition. The effect of APC on RAFb under hypoxic condition was blocked by $p 38$ inhibition. These results indicated that the effect of APC was via a p38-related pathway in RAFb under hypoxic conditions.

\section{DISCUSSION}

RA is a type of arthritis and a chronic autoimmune disorder (Huber et al. 2006; Xue et al. 2007). RA-related research is progressing steadily, however, the anti-inflammatory effect of APC on RA under hypoxic conditions is not fully understood. Previous reports show that APC reduces synovial hyperplasia in RA by inhibiting inflammatory signaling (Julovi et al. 2013). Our study focused on the effect of APC in hypoxic conditions. Our results showed that inflammatory signaling was downregulated by APC under hypoxic conditions. In these conditions, APC reduced $p 38$ phosphorylation and NF-kB expression to inhibit inflammation. A previous study showed that under hypoxic conditions, $p 38$ mitogen-activated protein kinase ( $p 38 \mathrm{MPAK})$ is essential for fibroblast proliferation and acts as a modulator of pro-inflammatory responses in rheumatological conditions (Mortimer et al. 2007). Indeed, if protease-activated receptors (PARs) are activated, they signal via $p 38$ to induce immune responses (Julovi et al. 2011; Riewald \& Ruf 2005). Thus, we expected that activation of $p 38$ by APC under hypoxic conditions would be involved in the proliferation and anti-inflammatory response of $\mathrm{RAFb}$. Our results were similar to our hypothesis (Figure 4(b)). Previous studies on APC and cell proliferation show APC inhibits proliferation (Julovi et al. 2013). However, our experiments showed that APC increased cell proliferation under normoxic and hypoxic conditions (Figure 1). These results confirmed previous studies (Xue et al. 2004). (a)

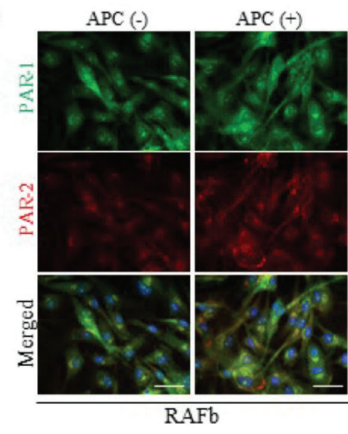

(d)

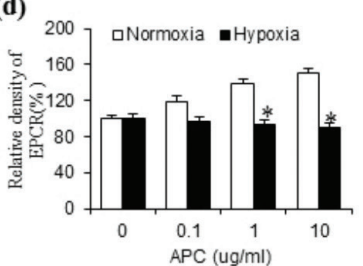

(g)

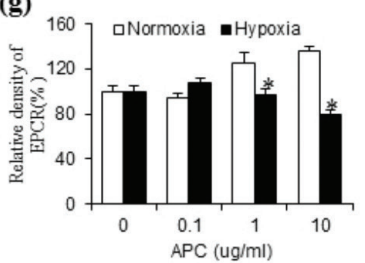

(b)

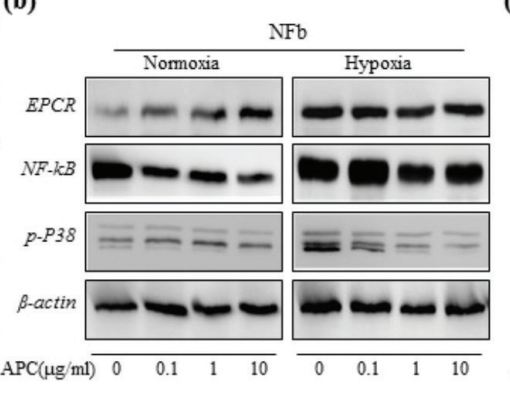

(c)

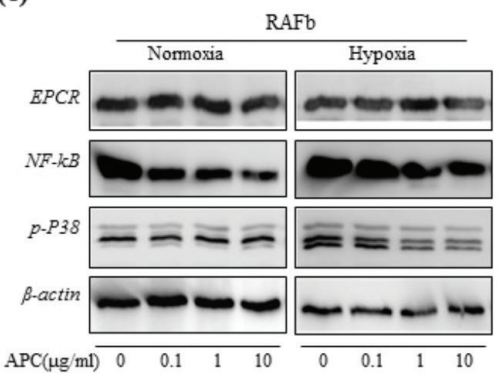

(e)

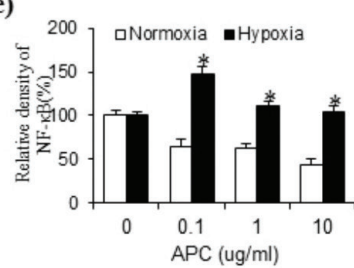

(h)

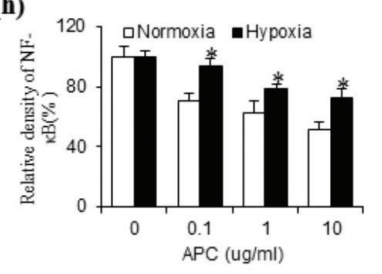

(f)

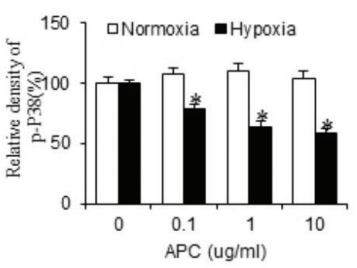

(i)

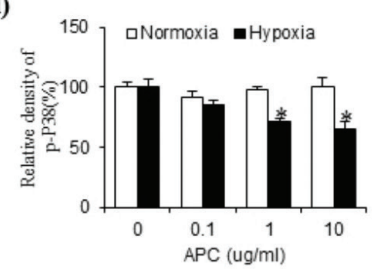

FIGURE 3. Change in protein levels in synovial fibroblasts with APC under normoxia and hypoxia. (a) PAR-1 and PAR-2 expression in $\mathrm{RAFb}$ in response to $1 \mu \mathrm{g} / \mathrm{mL}$ APC for $12 \mathrm{~h}$, detected by immunofluorescence. Scale bars $=20 \mu \mathrm{m}$. (b) and (c) NFb and RAFb were treated with activated protein $\mathrm{C}$ (APC; $0.1,1,10$ and $20 \mu \mathrm{g} / \mathrm{mL})$ for $72 \mathrm{~h}$ under normoxia $(21 \% \mathrm{O} 2)$ and hypoxia (1\% O2) and protein in cell lysates was detected by Western blot, (d)-(i) Protein level shown in (b), (c) determined by densitometry, Density value was calculated as expression versus control. Three independent experiments showed similar results. * $p<0.05$ versus normoxia by one-way ANOVA 

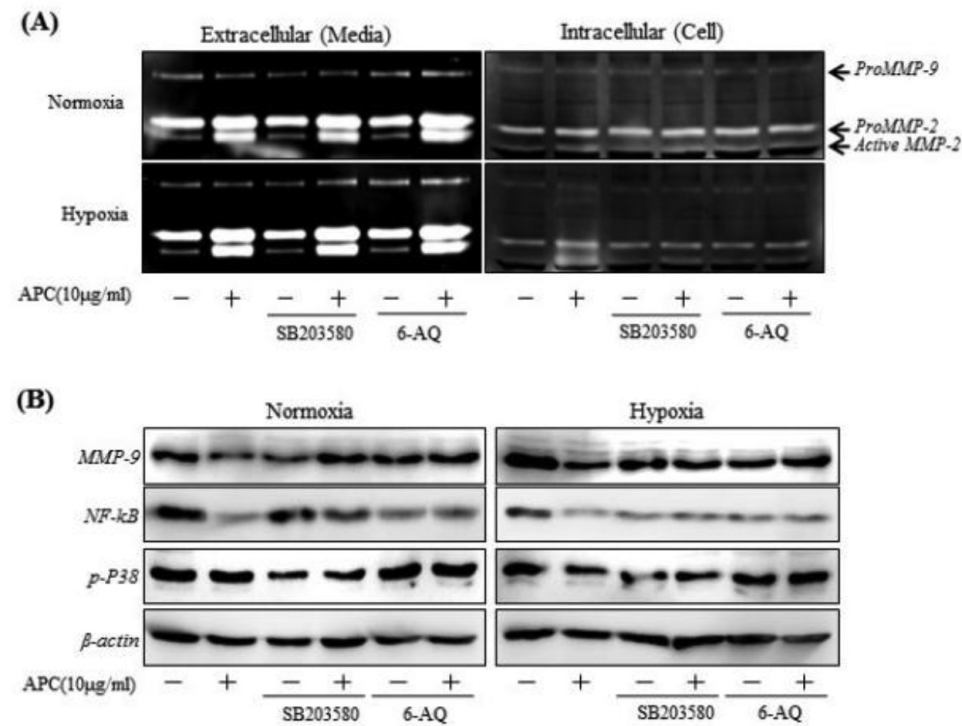

FIGURE 4. Involvement of NF-kB and $p 38$ in activation of matrix metalloproteinases MMP-2 and MMP-9 by activated protein C. (a) RAFb were treated with a combination of activated protein $\mathrm{C}$ APC $(10 \mu \mathrm{g} / \mathrm{mL})$ and 6-AQ $(1 \mu \mathrm{g} / \mathrm{mL})$, a specific inhibitor of NF-kB activation, or a $p 38$ inhibitor $(100 \mathrm{nM})$ for $72 \mathrm{~h}$ under normoxia $(21 \% \mathrm{O} 2)$ and hypoxia (1\% O2). MMP-2 and MMP-9 were detected in culture supernatants and cell lysates by zymography and (b) RAFb were treated under the conditions described in (a). Protein was detected by Western blots

APC induced EPCR expression in NFb under normoxic conditions, whereas under hypoxic conditions, EPCR expression was generally increased (Figure 2(b) \& 2(c)). EPCR has high-affinity binding for APC and APC treatment increased EPCR expression. However, in hypoxic conditions, EPCR expression was increased overall.

Of note, the change in MMPs with APC in normoxia was also observed in hypoxia. This evidence disproves that the anti-inflammatory effect of APC is reducing pain from RA by regulating MMP expression. In RAFb under hypoxic conditions, downregulation of MMP-9 by APC was stronger than normoxic conditions. APC activated MMP-2 in both normoxia and hypoxia (Figure 4). These results were similar with both $p 38$ and NF-kB inhibitors. These findings demonstrated that anti-inflammatory activity of APC was via $p 38$ signaling in synovial fibroblasts under hypoxia.

We also observed APC-induced protein expression. Under normoxic conditions, MMP-9 expression was reduced by APC. Similar results were observed in hypoxic conditions (Figure 4(b)). However, in hypoxic conditions, reduced expression of MMP-9 by APC was blocked by $p 38$ inhibition. In addition, inhibition of NF-kB increased MMP-9 expression compared to no APC treatment. Our most important finding was that APC inhibited inflammation via $p 38$-related signaling in RAFb under hypoxic conditions.

\section{CONCLUSION}

In summary, our findings provide features of APC in RA under hypoxic conditions. Hypoxia enhanced expression of EPCR and the effect of APC on RAFb via inhibition of p38 phosphorylation.

\section{ACKNOWLEDGEMENTS}

This paper was supported by research funds of Chonbuk National University in 2011.

\section{REFERENCES}

Akhavani, M.A., Madden, L., Buysschaert, I., Sivakumar, B., Kang, N. \& Paleolog, E.M. 2009. Hypoxia upregulates angiogenesis and synovial cell migration in rheumatoid arthritis. Arthritis Research \& Therapy 11(3): R64.

Arnett, F.C., Edworthy, S.M., Bloch, D.A., Mcshane, D.J., Fries, J.F., Cooper, N.S., Hunder, G.G. 1988. The American-Rheumatism-Association 1987 revised criteria for the classification of rheumatoid-arthritis. Arthritis and Rheumatism 31(3): 315-324.

Bauvois, B. 2012. New facets of matrix metalloproteinases MMP-2 and MMP-9 as cell surface transducers: Outside-in signaling and relationship to tumor progression. Biochimica Et Biophysica Acta-Reviews on Cancer 1825(1): 29-36.

Bouwens, E.A., Stavenuiter, F. \& Mosnier, L.O. 2013. Mechanisms of anticoagulant and cytoprotective actions of the protein C pathway. Journal of Thrombosis and Haemostasis 11(Suppl 1): 242-253.

Buisson-Legendre, N., Smith, S., March, L. \& Jackson, C. 2004. Elevation of activated protein $\mathrm{C}$ in synovial joints in rheumatoid arthritis and its correlation with matrix metalloproteinase 2. Arthritis Rheum. 50(7): 2151-2156.

Cheng, T., Petraglia, A.L., Li, Z., Thiyagarajan, M., Zhong, Z., Wu, Z., Liu, D., Maggirwar, S.B., Deane, R., Fernández, J.A., LaRue, B., Griffin, J.H., Chopp, M. \& Zlokovic, B.V. 2006. Activated protein C inhibits tissue plasminogen 
activator-induced brain hemorrhage. Nature Medicine 12(11): 1278-1285.

Danese, S., Vetrano, S., Zhang, L., Poplis, V.A. \& Castellino, F.J. 2010. The protein $C$ pathway in tissue inflammation and injury: Pathogenic role and therapeutic implications. Blood 115(6): 1121-1130.

Del Rey, M.J., Izquierdo, E., Usategui, A., Gonzalo, E., Blanco, F.J., Acquadro, F. \& Pablos, J.L. 2010. The transcriptional response of normal and rheumatoid arthritis synovial fibroblasts to hypoxia. Arthritis Rheum. 62(12): 3584-3594.

Esmon, C.T. 2012. Protein C anticoagulant system-antiinflammatory effects. Seminars in Immunopathology 34(1): 127-132.

Gao, W., McCormick, J., Connolly, M., Balogh, E., Veale, D.J. \& Fearon, U. 2015. Hypoxia and STAT3 signalling interactions regulate pro-inflammatory pathways in rheumatoid arthritis. Annals of the Rheumatic Diseases 74(6): 1275-1283.

Huber, L.C., Distler, O., Tarner, I., Gay, R.E., Gay, S. \& Pap, T. 2006. Synovial fibroblasts: Key players in rheumatoid arthritis. Rheumatology (Oxford) 45(6): 669-675.

Jackson, M.T., Moradi, B., Smith, M.M., Jackson, C.J. \& Little, C.B. 2014. Activation of matrix metalloproteinases 2, 9, and 13 by activated protein $\mathrm{C}$ in human osteoarthritic cartilage chondrocytes. Arthritis Rheumatol. 66(6): 1525-1536.

Jackson, M.T., Smith, M.M., Smith, S.M., Jackson, C.J., Xue, M. \& Little, C.B. 2009. Activation of cartilage matrix metalloproteinases by activated protein C. Arthritis Rheum. 60(3): 780-791.

Julovi, S.M., Shen, K., McKelvey, K., Minhas, N., March, L. \& Jackson, C.J. 2013. Activated protein C inhibits proliferation and tumor necrosis factor alpha-stimulated activation of $\mathrm{p} 38$, c-Jun NH2-terminal kinase (JNK) and akt in rheumatoid synovial fibroblasts. Molecular Medicine 19: 324-331.

Julovi, S.M., Xue, M., Dervish, S., Sambrook, P.N., March, L. \& Jackson, C.J. 2011. Protease activated receptor-2 mediates activated protein $\mathrm{C}$-induced cutaneous wound healing via inhibition of p38. American Journal of Pathology 179(5): 2233-2242.

Konisti, S., Kiriakidis, S. \& Paleolog, E.M. 2012. Hypoxia-a key regulator of angiogenesis and inflammation in rheumatoid arthritis. Nature Reviews Rheumatology 8(3): 153-162.

Lee, Y.J., Jeong, J.K., Seol, J.W., Xue, M.L., Jackson, C. \& Park, S.Y. 2013. Activated protein C differentially regulates both viability and differentiation of osteoblasts mediated by bisphosphonates. Experimental and Molecular Medicine 45(2): e9.

McKelvey, K., Jackson, C.J. \& Xue, M. 2014. Activated protein $\mathrm{C}$ : A regulator of human skin epidermal keratinocyte function. World Journal of Biological Chemistry 5(2): 169-179.

Melillo, G. 2011. Hypoxia: Jump-starting inflammation. Blood 117(9): 2561-2562.

Minhas, N., Xue, M., Fukudome, K. \& Jackson, C.J. 2010. Activated protein $\mathrm{C}$ utilizes the angiopoietin/Tie2 axis to promote endothelial barrier function. FASEB Journal 24(3): 873-881.

Mortimer, H.J., Peacock, A.J., Kirk, A. \& Welsh, D.J. 2007. p38 MAP kinase: Essential role in hypoxia-mediated human pulmonary artery fibroblast proliferation. Pulmonary Pharmacology and Therapeutics 20(6): 718-725.

Paleolog, E.M. 2009. The vasculature in rheumatoid arthritis: Cause or consequence? International Journal of Experimental Pathology 90(3): 249-261.
Rankin, E.B. \& Giaccia, A.J. 2008. The role of hypoxia-inducible factors in tumorigenesis. Cell Death \& Differentiation 15(4): 678-685.

Riewald, M., Petrovan, R.J., Donner, A., Mueller, B.M. \& Ruf, W. 2002. Activation of endothelial cell protease activated receptor 1 by the protein C pathway. Science 296(5574): 1880-1882.

Riewald, M. \& Ruf, W. 2005. Protease-activated receptor-1 signaling by activated protein $\mathrm{C}$ in cytokine-perturbed endothelial cells is distinct from thrombin signaling. Journal of Biological Chemistry 280(20): 19808-19814.

Ruf, W. 2004. Protease-activated receptor signaling in the regulation of inflammation. Critical Care Medicine 32(5): S287-S292.

Ryu, J.H., Chae, C.S., Kwak, J.S., Oh, H., Shin, Y., Huh, Y.H. \& Chun, J.S. 2014. Hypoxia-inducible factor-2 alpha is an essential catabolic regulator of inflammatory rheumatoid arthritis. Plos Biology 12(6): e1001881.

Sela-Passwell, N., Rosenblum, G., Shoham, T. \& Sagi, I. 2010. Structural and functional bases for allosteric control of MMP activities: Can it pave the path for selective inhibition? Biochim Biophys Acta 1803(1): 29-38.

Seol, J.W., Lee, Y.J., Jackson, C.J., Sambrook, P.N. \& Park, S.Y 2011. Activated protein $C$ inhibits bisphosphonate-induced endothelial cell death via the endothelial protein $\mathrm{C}$ receptor and nuclear factor-kappaB pathways. International Journal of Molecular Medicine 27(6): 835-840.

Thiyagarajan, M., Cheng, T. \& Zlokovic, B.V. 2007. Endothelial cell protein $\mathrm{C}$ receptor: role beyond endothelium? Circulation Research 100(2): 155-157.

Xue, M. \& Jackson, C.J. 2015. Novel functions of the anticoagulant activated protein $\mathrm{C}$ in maintaining skin barrier integrity to impact on skin disease. Pathobiology 82(2): 100-106.

Xue, M., March, L., Sambrook, P.N. \& Jackson, C.J. 2007. Differential regulation of matrix metalloproteinase 2 and matrix metalloproteinase 9 by activated protein C: Relevance to inflammation in rheumatoid arthritis. Arthritis Rheum. 56(9): 2864-2874.

Xue, M., Thompson, P., Kelso, I. \& Jackson, C. 2004. Activated protein $\mathrm{C}$ stimulates proliferation, migration and wound closure, inhibits apoptosis and upregulates MMP-2 activity in cultured human keratinocytes. Experimental Cell Research 299(1): 119-127.

Xue, M.L., Campbell, D., Sambrook, P.N., Fukudome, K. \& Jackson, C.J. 2005. Endothelial protein C receptor and protease-activated receptor-1 mediate induction of a woundhealing phenotype in human keratinocytes by activated protein C. Journal of Investigative Dermatology 125(6): 1279-1285.

Xue, M.L., March, L., Sambrook, P.N., Fukudome, K. \& Jackson, C.J. 2007. Endothelial protein C receptor is overexpressed in rheumatoid arthritic (RA) synovium and mediates the antiinflammatory effects of activated protein $\mathrm{C}$ in RA monocytes. Annals of the Rheumatic Diseases 66(12): 1574-1580.

Xue, M.L., Shen, K., McKelvey, K., Li, J., Chan, Y.K.A., Hatzis, V., Jackson, C.J. 2014. Endothelial protein C receptorassociated invasiveness of rheumatoid synovial fibroblasts is likely driven by group $\mathrm{V}$ secretory phospholipase $\mathrm{A}(2)$. Arthritis Research \& Therapy 16(1): R44.

Xue, M.L., Thompson, P., Kelso, I. \& Jackson, C. 2004. Activated protein $\mathrm{C}$ stimulates proliferation, migration and wound closure, inhibits apoptosis and upregulates MMP-2 activity 
in cultured human keratinocytes. Experimental Cell Research 299(1): 119-127.

Yang-Gyu Park, Jawun Choi, Inkyu Song, Sang-Youel Park \& Jae-Won Seol

Bio-Safety Research Institute

College of Veterinary Medicine

Chonbuk National University

Iksan, Jeonbuk 54596

Republic of Korea
Christopher J. Jackson

Sutton Arthritis Research Laboratories

Institute of Bone and Joint Research

Kolling Institute of Medical Research

University of Sydney at Royal North Shore Hospital

St. Leonards, NSW2065

Australia

*Corresponding author; email: jwsseol@jbnu.ac.kr

Received: 4 March 2016

Accepted: 13 March 2017 